\title{
Maciej Mitręga*
}

Uniwersytet Ekonomiczny w Katowicach

\section{DYNAMICZNE ZDOLNOŚCI - WZLOTY I UPADKI PARADYGMATU STRATEGII*}

\begin{abstract}
STRESZCZENIE
Dynamiczne zdolności (dynamic capabilities) to jeden z najbardziej wpływowych paradygmatów współczesnego zarządzania strategicznego. W niniejszym artykule podjęto próbę odpowiedzi na pytanie: co wyróżnia podejście dynamicznych zdolności od innych paradygmatów strategii, a także jakie są mocne i słabe strony tego podejścia. Rozważania te przeprowadzono na tle istniejącego stanu badań empirycznych na temat tego paradygmatu, a także zarzutów formułowanych pod jego adresem. Pomimo pojawiających się kontrowersji, dalsze akademickie perspektywy dla dynamicznych zdolności rysują się obiecująco.
\end{abstract}

Słowa kluczowe: dynamiczne zdolności, zarządzanie strategiczne

\section{Wprowadzenie}

Współcześni menedżerowie ,żyją w ciekawych czasach”, ponieważ borykają się nie tylko z niedostatkami zasobów i kompetencji własnych przedsiębiorstw, ale muszą antycypować wielokierunkowe i nierzadko sprzeczne zmiany zachodzące

* Adres e-mail: maciej.mitrega@ue.katowice.pl

${ }^{* *}$ Badania prezentowane $\mathrm{w}$ niniejszym artykule były finansowane przez Narodowe Centrum Nauki w ramach projektu nr 2015/19/B/HS4/01699. 
w otoczeniu. Dynamika tych zmian jest wysoka, co wiąże się z występowaniem zmian nieciągłych. Nie dotyczy to zresztą tylko zmian zachodzących w obszarze technologicznym, związanych ze skokowym rozwojem mediów społecznościowych i nowymi aplikacjami dla użytkowników indywidualnych, w tym tych dedykowanych na urządzenia mobilne. Akurat zmiany w otoczeniu technologicznym nie dotykają w równym stopniu wszystkich podmiotów gospodarczych, ale odczuwają je przede wszystkim podmioty z branż tzw. nowych technologii. Zmiany nieciągłe zachodzą jednak również w takich obszarach, jak otoczenie prawne i polityczne (np. Brexit, niepewne losy CETA, izolacjonizm Rosji, zapowiadane nowe konstrukcje podatkowe w Polsce), co jest powszechnie odczuwalne i wiąże się z szerzej zakrojonymi procesami zachodzącymi w obszarze społeczno-kulturowym, a zwłaszcza obserwowanym zwrotem w stronę wartości konserwatywnych i nacjonalistycznych zarówno w Europie, jak i USA.

W niepewnym otoczeniu szczególnej wagi nabierają te wszystkie strategie, metody i techniki zarządzania, które pozwalają organizacjom nie tylko przetrwać, ale również przewidywać zmiany zachodzące w otoczeniu i odpowiednio się do nich dostosować. Nie ulega wątpliwości, że teoria ekonomii dostrzega znaczenie tych problemów już od dłuższego czasu, o czym świadczy chociażby to, że już w latach 30 . XX wieku stawiano tezę, że przewaga konkurencyjna jest oparta na innowacjach i kreatywnej destrukcji istniejących zasobów (Schumpeter, 1934). Tym niemniej, to właśnie koncepcja dynamicznych zdolności organizacji (DZO albo ang. dynamic capabilities) uczyniła głównym przedmiotem swojego zainteresowania zmiany zachodzące $w$ organizacji i w jej otoczeniu. Koncepcja ta podjęła próbę odpowiedzi na pytanie: jakie narzędzia należy wypracować w organizacji, aby ta zestandaryzowała, usystematyzowała zmiany, w tym te nieciągłe, które są z natury obarczone dużą dozą niepewności czy nawet chaosu, a zatem niezbyt poddają się wszelkiej standaryzacji. DZO uzyskały bardzo duży rozgłos w środowisku akademickim, co widoczne jest w międzynarodowych bazach bibliograficznych (np. ponad 26 tys. cytowań dla samego artykułu Teece, Pisano, Shuen, 19971), a także, do pewnego stopnia, w rosnącym zainteresowaniu tą koncepcją wśród polskich naukowców (Bratnicki, Olszak, Kisielnicki, 2014; Stawasz, 2015; Strużyna, 2012).

Od końca lat 90. ubiegłego stulecia, czyli od czasu, gdy koncepcja ta pojawiła się w obiegu akademickim, minęły już prawie dwie dekady, co pozwala spojrzeć na DZO z pewnym dystansem, w duchu konstruktywnie-krytycznym. W związku z powyż-

\footnotetext{
${ }^{1}$ Dokładnie 26271 cytowań na podstawie danych z bazy Googlescholar z 19 listopada 2016 r.
} 
szym, celem tego artykułu jest określenie specyficznych cech i tendencji rozwojowych DZO, a także określenie mankamentów, które ograniczają jej wartość eksploatacyjną i utrudniają dalszy rozwój. Cel ten zostanie osiągnięty w kilku krokach. Po pierwsze, zdefiniowane zostaną dynamiczne zdolności organizacji oraz różnice pomiędzy tzw. zasobową koncepcją organizacji a koncepcją DZO. Po drugie, wskazany zostanie kierunek stopniowego przyrostu wiedzy empirycznej w obszarze DZO. Po trzecie, omówione zostaną podstawowe zarzuty formułowane wobec DZO. W ostatniej części artykułu podjęta zostanie próba odpowiedzi na pytanie, czy zarzuty stawiane wobec DZO podważają naukową wartość wyłaniającej się koncepcji.

\section{DZO - cechy specyficzne}

Korzeni koncepcji DZO można doszukiwać się różnych obszarach teorii zarządzania, a zwłaszcza w tzw. behawioralnej szkole zarządzania (Cyert, March, 1963), która podkreślała złożoność wprowadzania wszelkich zmian w organizacji oraz podległość przeszłym doświadczeniom oraz ewolucyjnej szkole zarządzania (Nelson, Winter, 1982), która wprowadziła pojęcie rutyn organizacji i konieczność ich rozwijania. Tyn niemniej, największy wpływ na powstanie i rozwój koncepcji DZO miała tzw. zasobowa teoria przewagi konkurencyjnej albo resource-based view - RBV (Barney, 1991; Wernerfelt, 1984). Ta ostatnia zakłada, że źródłem trwałej przewagi konkurencyjnej jest zbieranie i posiadanie zasobów o specyficznych cechach, takich jak cenność, rzadkość i niepełna zastępowalność. DZO oparte są na tym samym założeniu, jednak w mniejszym stopniu koncentrują się na samym zbieraniu strategicznych zasobów i ich wykorzystywaniu, a w większym - na tym, w jaki sposób zasoby takie można modyfikować. Można zatem przyjąć, że koncepcja DZO jest swoistą odpowiedzią na dość statyczny charakter zasobowej teorii.

Chociaż sam termin dynamiczne zdolności (dynamic capabilities) został wymyślony przez Teece'a i Pisano (1994), można przyjąć, że na to, jak dziś w literaturze przedmiotu postrzega się i bada dynamiczne zdolności, największy wpływ wywarły prace dwóch zespołów badaczy z przełomu wieków, tj. Teece’a i in. (1997) oraz Eisenhardt i Martina (2000). Obie te prace uzyskały największą liczbę cytowań spośród wszystkich poruszających tematykę dynamicznych zdolności. Nie są ze sobą w pełni kompatybilne, ale można uznać je za komplementarne, zresztą widać, że większość projektów badawczych z zakresu DZO nawiązuje do obu tych prac. 
Mając świadomość występowania pewnej wariancji w dotychczasowych konceptualizacjach dynamicznych zdolności, warto pokusić się o wskazanie elementów łączących te nurty. Inaczej mówiąc: co wyróżnia program badawczy DZO od innych programów? Po pierwsze, prace z zakresu DZO wskazują na rosnącą dynamikę zmian w otoczeniu, co podważa możliwość ciągłego wykorzystywania wciąż tej samej wiązki zasobów jako narzędzia rywalizacji z konkurentami. W tym sensie można powiedzieć, że koncepcja DZO nie jest zbyt optymistyczna wobec możliwości uzyskania tzw. trwałej przewagi konkurencyjnej (sustainable competitive advantage) i zakłada raczej, że jedynym źródłem długoterminowej przewagi jest wpisanie w kulturę organizacji dążności do systematycznej zmiany strategicznej i podejmowanie kroków umożliwiających tę zmianę. Po drugie, koncepcja DZO koncentrują się bardziej na samym tworzeniu unikalnych zasobów niż na wykorzystywaniu tych zasobów w sposób prowadzący do uzyskania ponadprzeciętnych wyników. W rozumowaniu ścieżek przyczynowo-skutkowych (Konarski, 2014) można zatem przyjąć, że DZO dotyczą przede wszystkim antecedencji modyfikacji zasobowych i na wyniki organizacji mają raczej wpływ pośredni (poprzez zasoby) niż bezpośredni. Po trzecie, DZO doszukują się mechanizmu modyfikacji wiązki zasobów w tzw. rutynach organizacji, czyli ,,regularnych i przewidywalnych wzorcach zachowań” członków organizacji (Nelson, Winter, 1982, s. 14). Co prawda, stopień złożoności tak rozumianych rutyn różni się w zależności od dynamiki zmian w otoczeniu (Eisenhardt, Martin, 2000), to jednak nawet w przypadku bardzo zmiennych rynków konieczne jest wypracowanie pewnych wspólnych procesów, które umożliwiałyby szybkie dostosowanie organizacji do zmian $\mathrm{w}$ otoczeniu. $\mathrm{W}$ takich warunkach rutyny mogą charakteryzować się większym poziomem elastyczności, np. co do szczegółów rozdziału obowiązków w ramach struktury organizacji czy zbiorem etapów wdrożenia. Po czwarte, DZO zakładają wypracowanie w organizacji takich narzędzi, które umożliwiałyby efektywne monitorowanie zmian w otoczeniu i wykorzystywanie tak budowanej wiedzy do rozwijania nowych zasobów i kompetencji w ramach organizacji. Można zatem przyjąć, że organizacja posiadająca odpowiednie dynamiczne zdolności ma pewien system wczesnego ostrzegania i staje się „elastyczna” (flexible) a nawet zwinna (agile) (Grudzewski, Hejduk, 2011; Nogalski, Niewiadomski, 2012; Trzcieliński, 2011) w stosunku do tego, co dzieje się w otoczeniu. Po piąte, nie ma jednej „dynamicznej zdolności”, ale jest wiele dynamicznych zdolności, co dotyczy zarówno możliwości posiadania takich zdolności przez więcej niż jedno przedsię- 
biorstwo w danym sektorze, jak i tego, że dynamiczne zdolności rozwijać się mogą w rozmaitych obszarach funkcjonalnych organizacji (np. R\&D, alianse, marketing, zarządzanie łańcuchem dostaw).

Biorąc pod uwagę powyższe wspólne cechy koncepcji DZO, można przyjąć, że dynamiczne zdolności odnosza się do takich wzorców zachowań członków organizacji, które koncentrują się na modyfikacji istniejących zasobów i kompetencji organizacji w taki sposób, że organizacja staje się lepiej dostosowana do warunków otoczenia.

\section{Przyrost wiedzy empirycznej na temat DZO}

Prace koncepcyjne w zakresie dynamicznych zdolności mają bardzo duże znaczenie, gdyż bez nich nie uda się wypracować twardego rdzenia wyłaniającej się teorii, co może spowodować, że rozmaici badacze będą analizować dynamiczne zdolności posługując się niekompatybilnymi kategoriami pojęciowymi. W takiej sytuacji przyrost wiedzy w określonym programie badawczym staje się właściwie niemożliwy. Tym niemniej, w toku ostatniej dekady DZO dały asumpt do powstania wielu prac o charakterze empirycznym, które pokazują kierunki rozwoju tego paradygmatu, w tym ilustrują, jak badacze zarządzania traktują DZO pod względem pomiarowym. Można w tym względzie wskazać na podstawowe tendencje.

Dotychczasowe badania dostarczyły przesłanek empirycznych wskazujących na to, że DZO ułatwiają uzyskiwanie przewagi konkurencyjnej. Teza ta była testowana przede wszystkim w pewnych szczegółowych obszarach funkcjonalnych, takich chociażby jak DZO w marketingu (Weerawardena, Mort, Salunke, Knight, Liesch, 2015) czy DZO w zakresie aliansów interorganizacyjnych (Mitrega, Pfajfar, 2015). Odnaleźć można również prace, które podjęły próbę pomiaru i empirycznego testowania wpływu ogólnych DZO na przewagę kompetencyjną uzyskiwaną w obszarach takich chociażby, jak NPD (Pavlou, El Sawy, 2011) czy technologia produkcji (Wilden, Gudergan, 2015).

W przeciwieństwie do pierwotnego punktu widzenia, że DZO są przydatne raczej w dużych przedsiębiorstwach, dotychczasowe badania empiryczne sugerują, że DZO przydają się także w małych firmach oraz zróżnicowanych branżach, a nie tylko w sektorze IT (Døving, Gooderham, 2008; Salvato, 2003). Dotychczasowe badania sugerują również, że DZO mogą być skutecznie stosowne przez przedsiębiorstwa działające w otoczeniu o zróżnicowanym poziomie zmienności (environ- 
mental dynamism), jednak efekty osiągane przez te same DZO na bardzo zmiennych rynkach mogą być większe niż efekty osiągane przez DZO na rynkach względnie stabilnych (Drnevich, Kriauciunas, 2011; Wilden, Gudergan, 2015).

\section{Główne zarzuty wobec koncepcji DZO}

Choć koncepcja DZO zakreśla bez wątpienia jedną z najbardziej wpływowych i dynamicznie rozwijających się szkół współczesnego zarządzani strategicznego, bardzo szybko pojawiły się wobec niej głosy krytyczne. Być może najbardziej wyrazistą wadą podkreślaną w środowisku naukowym jest dość abstrakcyjny charakter tej koncepcji. Po prostu, DZO bywają opisywane w tak ogólnikowy sposób, że czasem trudno jest dostrzec jakieś konkretne działania, które przedsiębiorstwo mogłoby podjąć, aby lepiej dostosować swoją bazę kompetencyjną do zmian w otoczeniu. DZO krytykowane są często za tautologiczny charakter niektórych założeń, zwłaszcza za twierdzenie, że stanowią źródło przewagi konkurencyjnej. Takie podejście rzeczywiście dostrzegane jest w niektórych kluczowych pracach koncepcyjnych, a także w badaniach empirycznych, gdzie analizie poddaje się bezpośrednie korelacje pomiędzy jakimiś DZO, w różnych obszarach funkcjonalnych, a wynikami rynkowymi bądź finansowymi osiąganymi przez przedsiębiorstwo. Zarzut tautologii w takim przypadku wydaje się uzasadniony, gdy projekt badawczy stosuje bardzo proste sposoby operacjonalizacji złożonego konstruktu DZO, w przypadku których menedżerowie organizacji proszeni są o określenie tego, co ich organizacja „umie” (can do approach). Wydaje się to dużym uproszczeniem, ponieważ w takim ujęciu koncepcja DZO traci niejako swoją odrębność wobec RBV, pomijając mniej lub bardziej złożone mechanizmy prowadzące do biegłości organizacji w określonym obszarze. Niedostateczny rozwój modeli pomiarowych to zresztą kolejny zarzut formułowany wobec koncepcji DZO. W wielu badaniach stosuje się różne pośrednie sposoby pomiaru DZO (proxy), co sprawia wrażenie braku precyzji, a brak zestandaryzowanych narzędzi pomiarowych utrudnia zewnętrzną walidację uzyskanych wyników. W ocenie DZO jako paradygmatu strategii zasadniczą wątpliwość budzi również to, że w ich zrębach teoretycznych pojawia się duże zróżnicowanie, a nawet dostrzec można pewne sprzeczności. Znamienne, że dwie najbardziej wpływowe prace z tego obszaru (Eisenhardt, Martin, 2000; Teece i in., 1997) tylko w części przedstawiają taki sam obraz dynamicznych zdolności organizacji i sięgają do 
wspólnych korzeni teoretycznych, a w części, zwłaszcza w szczegółach, tworzą wizje odmienne. Taki stan rzeczy ukształtował pewną dwutorowość w badaniach nad dynamicznymi zdolnościami organizacji, które realizowane były w ciągu ostatniej dekady (Di Stefano, Peteraf, Verona, 2014; Peteraf, Di Stefano, Verona, 2013). Dwutorowość ta dotyczy takich spraw, jak chociażby to, czy DZO mogą być przydatne na wszystkich rynkach oraz w jakim stopniu stabilne i złożone muszą być wzorce zachowań stanowiące ich trzon.

\section{Perspektywy dla DZO}

Dwie dekady, które upłynęły od czasu, gdy termin DZO został wprowadzony do literatury przedmiotu, pozwalają z dystansem spojrzeć na miejsce, które DZO zajęły w teorii zarządzania, zwłaszcza w zarządzaniu strategicznym. Przez lata koncepcja DZO traktowana była zaledwie jako uzupełnienie wobec zasobowej teorii przewagi konkurencyjnej (RBV), jednak skokowy przyrost zainteresowania DZO obserwowany w czołowych czasopismach naukowych pozwala uznać, że DZO wyłaniają się jako samodzielny paradygmat strategii. Paradygmat ten wpływa na szereg subdyscplin zarządzania, takich jak zarządzanie marketingiem, zarządzanie produkcją czy zarządzanie łańcuchem dostaw. Widoczny jest pewien niedostatek badań empirycznych w zakresie DZO, zwłaszcza tych opartych na licznych próbach badawczych, jednak dotychczasowe prace tego typu dostarczyły przesłanek za tym, że konstrukt DZO jest trafny w sensie nomologicznym (Czakon, 2014), tzn. wyjaśnia zmienność pewnych cech przedsiębiorstw traktowanych jako wyznaczniki skutecznego zarządzania.

Występowanie zarzutów wobec DZO nie jest szczególnie zaskakujące, jeśli weźmiemy pod uwagę, że DZO to stosunkowo młody paradygmat zarządzania, a poglądy rywalizujące ze sobą o pierwszeństwo są motorem napędowym tworzenia się twardego rdzenia każdej teorii naukowej (Kuhn, 1968; Lakatos, 1976). Wydaje się, że zarzuty formułowane wobec koncepcji DZO będą po prostu ukierunkowywać dalsze badania na jej temat. Przykładowo, zarzut „ogólnikowości” i „niedostatku modeli pomiarowych" będzie dawał asumpt do częstszego stosowania jakościowych metod badawczych oraz większej dbałości o testowanie rzetelności i trafności narzędzi pomiarowych. To samo zresztą dotyczy zarzutu „tautologii”. Konstruktywną konsekwencją tak sformułowanego zarzutu będzie większa dbałość o to, aby zmienne wprowadzane do konkretnych modeli badawczych (np. w konkretnym obsza- 
rze zarządzania) były nie tylko wewnętrznie trafne, ale również istotnie różne od siebie nawzajem. Niespójności dostrzegalne w kluczowych pracach wytyczających mainstream DZO będą przypuszczalnie ulegać stopniowemu zatarciu, zarówno na gruncie badań empirycznych (np. dynamizm otoczenia jako stymulator dla sukcesu DZO, a nie warunek sukcesu DZO), a także w zakresie prac koncepcyjnych, które w ostatnich latach podejmowały próby wyjaśnienia zaistniałych niezgodności i proponowały modele spajające odmienne poglądy (Di Stefano i in., 2014; Peteraf i in., 2013). Swoista dwutorowość w rozwoju koncepcji DZO nie jest zresztą niczym niezwykłym, ponieważ w naukach o zarządzaniu w obrębie jednego paradygmatu często konkurują ze sobą różne podejścia (por. Mitrega, 2006, 2008; Witczak, 2008).

Reasumując, perspektywy wobec koncepcji DZO rysują się umiarkowanie optymistycznie. Koncepcja ta zaiste doświadcza swoich „wzlotów” i „upadków”, co nie powinno prowadzić do „wylania dziecka wraz z kąpielą”. Podstawy empiryczne dla wyłaniającego się paradygmatu stopniowo przyrastają, podobnie jak i klaruje się twardy rdzeń tej koncepcji. Silnym argumentem dowartościowujący koncepcję DZO jest to, że koncepcja ta stanowi logiczną odpowiedź na mega-tendencje obserwowane w otoczeniu biznesowym. Zmiany stają się coraz bardziej skokowe, a ich antycypacja stanowi ważne działanie w zarządzaniu współczesnymi organizacjami.

\section{Literatura}

Barney, J.B. (1991). Firm Resources and Sustained Competitive Advantage. Journal of Management, 17 (1), 99-120.

Bratnicki, M., Olszak, C., Kisielnicki, J. (2014). Twórczość organizacyjna i ICT jako nowa perspektywa zarządzania organizacją. Informatyka Ekonomiczna, 1, 31 .

Cyert, R.M., March, J.G. (1963). A Behavioral Theory of the Firm. Englewood Cliffs: Prentice Hall.

Czakon, W. (2014). Kryteria oceny rygoru metodologicznego badań w naukach o zarządzaniu. Organizacja i Kierowanie, 1, 51-62.

Di Stefano, G., Peteraf, M., Verona, G. (2014). The Organizational Drivetrain: A Road to Integration of Dynamic Capabilities Research. The Academy of Management Perspectives, 28 (4), 307-327.

Døving, E., Gooderham, P.N. (2008). Dynamic Capabilities as Antecedents of the Scope of Related Diversification: The Case of Small Firm Accountancy Practices. Strategic Management Journal, 29 (8), 841-857. 
Drnevich, P.L., Kriauciunas, A.P. (2011). Clarifying the Conditions and Limits of the Contributions of Ordinary and Dynamic Capabilities to Rrelative Firm Performance. Strategic Management Journal, 32 (3), 254-279.

Eisenhardt, K.M., Martin, J.A. (2000). Dynamic Capabilities: What Are They? Strategic Management Journal, 21 (10-11), 1105-1121.

Grudzewski, W.M., Hejduk, I.K. (2011). Przedsiębiorstwo przyszłości. Zmiany paradygmatów zarządzania. Master of Business Administration, 19 (1), 95-111.

Konarski, R. (2014). Modele równań strukturalnych: teoria i praktyka. Warszawa: Wydawnictwo Naukowe PWN.

Kuhn, T.S. (1968). Struktura rewolucji naukowych. Warszawa: PWN.

Lakatos, I. (1976). Falsification and the Methodology of Scientific Research Programmes. W: I. Lakatos, A. Musgrave (red.), Criticism and the Growth of Knowledge (s. 205-259). Cambridge University Press.

Mitrega, M. (2006). Building Strong Relationships between Services' Providers and Consumers: Evidence from Poland. Transformations in Business \& Economics, 5 (2), 148-162.

Mitrega, M., Pfajfar, G. (2015). Business Relationship Process Management as Company Dynamic Capability Improving Relationship Portfolio. Industrial Marketing Management, 46 (April), 193-203.

Mitręga, M. (2008). Determinanty korzystnych relacji z klientami. W poszukiwaniu różnych strategii marketingu relacji na rynku B2B. Marketing i Rynek, 3, 13-19.

Nelson, R.R., Winter, S.G. (1982). An Evolutionary Theory of Economic Change. Cambridge, MA: Harvard University Press.

Nogalski, B., Niewiadomski, P. (2012). Kryterium zwinnego zakładu wytwórczego - strategiczny model biznesowy w przedsiębiorstwie wiedzy. Prace Naukowe Uniwersytetu Ekonomicznego we Wrocławiu, 260, 314-327.

Pavlou, P.A., El Sawy, O.A. (2011). Understanding the Elusive Black Box of Dynamic Capabilities. Decision Sciences, 42 (1), 239-273.

Peteraf, M., Di Stefano, G., Verona, G. (2013). The Elephant in the Room of Dynamic Capabilities: Bringing Two Diverging Conversations Together. Strategic Management Journal, 34 (12), 1389-1410.

Salvato, C. (2003). The Role of Micro-Strategies in the Engineering of Firm Evolution. Journal of Management Studies, 40 (1), 83-108.

Schumpeter, J.A. (1934). The Theory of Economic Development: An Inquiry into Profits, Capital, Credit, Interest, and the Business Cycle. Vol. 55. Transaction Publishers.

Stawasz, E. (2015). Dynamiczna zdolność innowacyjna - wybrane zagadnienia. Folia Oeconomica, 4 (305). 
Strużyna, J. (2012). Wybrane założenia polityki wynagrodzeń wspartej na relacji „dynamiczne zdolności - rutyny”. Zarządzanie Zasobami Ludzkimi, 5 (88), 89-108.

Teece, D.J., Pisano, G. (1994). The Dynamic Capabilities of Firms: An Introduction. Industrial and Corporate Change, 3 (3), 537.

Teece, D.J., Pisano, G., Shuen, A. (1997). Dynamic Capabilities and Strategic Management. Strategic Management Journal, 18 (7), 509-533.

Trzcieliński, S. (2011). Przedsiębiorstwo zwinne. Poznań: Wydawnictwo Politechniki Poznańskiej.

Weerawardena, J., Mort, G., Salunke, S., Knight, G., Liesch, P. (2015). The Role of the Market Sub-system and the Socio-technical Sub-system in Innovation and Firm Performance: A Dynamic Capabilities Approach. Journal of the Academy of Marketing Science, 43 (2), 221-239.

Wernerfelt, B. (1984). A Resource-based View of the Firm. Strategic Management Journal, 5 (2), 171-180.

Wilden, R., Gudergan, S. (2015). The Impact of Dynamic Capabilities on Operational Marketing and Technological Capabilities: Investigating the role of Environmental Turbulence. Journal of the Academy of Marketing Science, 43 (2), 181-199.

Witczak, O. (2008). Budowanie związków z klientami na rynku business to business: teoria i praktyka. Warszawa: CeDeWu.

\title{
DYNAMIC CAPABILITIES - UPS AND DOWNS OF STRATEGY PARADIGM
}

\begin{abstract}
Dynamic capabilities are one of most influential paradigm in contemporary strategic management. This paper addresses the problem of factors distinguishing dynamic capabilities from other strategy paradigms, as well as weaknesses and advantages of this theoretical approach. The discussion is undertaken in the context of existing empirical research on this paradigm and controversies presented in the literature in relation to it. Although controversies are substantial, perspectives for further development of dynamic capabilities approach are optimistic.
\end{abstract}

Keywords: dynamic capabilities, strategic management

JEL codes: M00, M10 